\title{
Kernos
}

Revue internationale et pluridisciplinaire de religion grecque antique

6 | 1993

Varia

\section{Creative Euphoria. Dionysos and the Theatre}

\section{Synnøve Des Bouvrie}

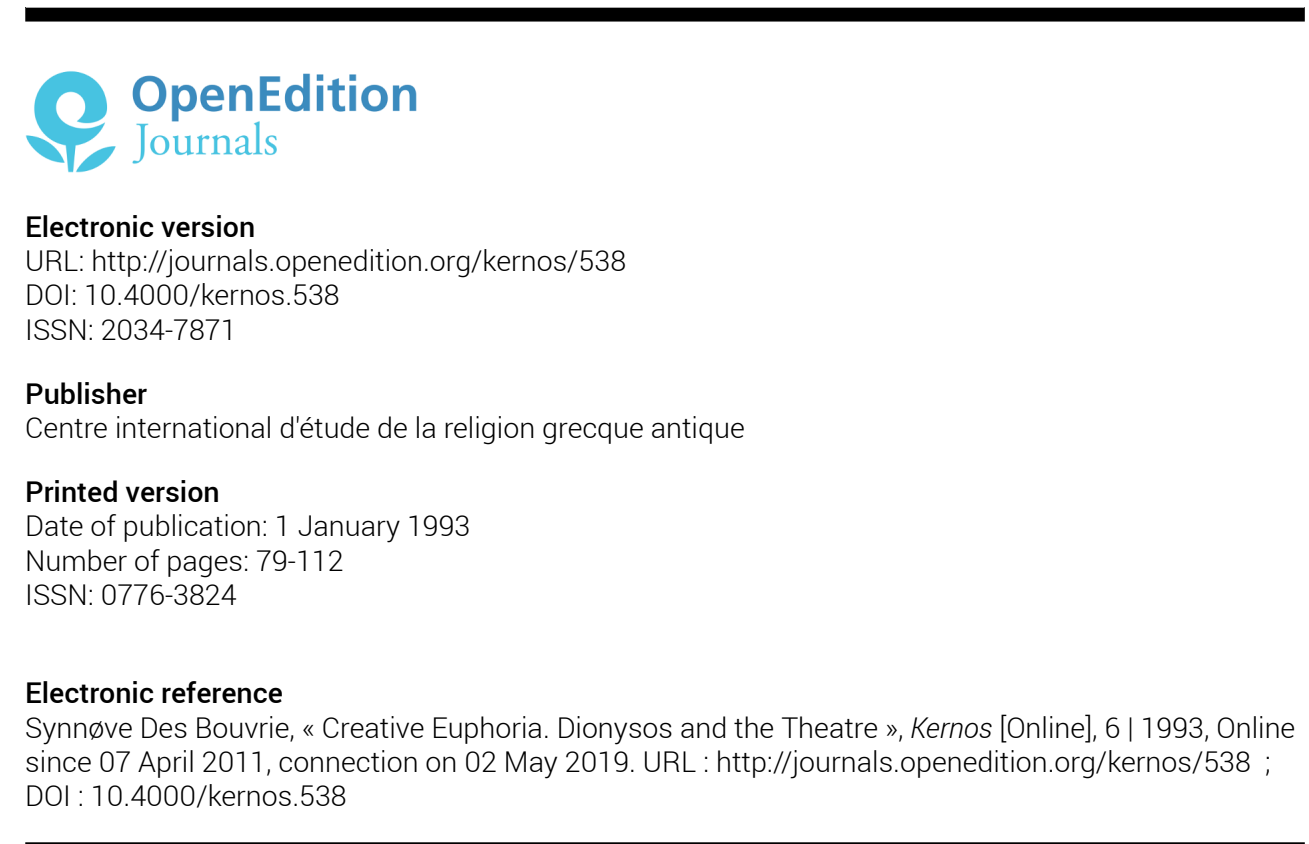

Kernos 
Kernos , 6 (1993), p. 79-112.

\section{CREATIVE EUPHORIA.}

\section{DIONYSOS AND THE THEATRE*}

\section{Introduction}

"Nothing to do with Dionysos" goes the Ancient proverb referring to the choice of theme in Greek theatre, the drama that was brought to life within the rites and the temenos of Dionysos ${ }^{1}$. As long as we can judge the matter, the plays that stage the god or his retinue are extremely rare, and of these remain only Euripides' Bakkhai, Aristophanes' Batrakhoi and satyr-drama ${ }^{2}$. However, if Classical drama shows little affinity with Dionysos, what relations does the theatre have with his other cult manifestations? In spite of innumerable monographs and discussions of the Dionysos cult that have been published the last decennia, the

* I express my gratitude to the Norwegian Research Council for Science and the Humanities (NAVF) for their financial support which enabled me to study the subject in Greece 1988 during which stay this study was completed. Short versions were published earlier, in Norwegian and in English, S. DES BouvRIE, Kreativ eufori, in T. EIDE, T. HÄGG (eds.), Dionysos og Apollon. Religion og samfunn $i$ antikkens Hellas, Bergen, 1989 (Skrifter utgitt av Det norske institutt $i$ Athen, 1), p. 133-142 and S. DEs BouvrIe, Women in Greek Tragedy. An Anthropological Approach, Oslo, 1990 (Symbolae Osloenses Fasc. Suppl. 27), p. 83-86. For the abbreviations of Ancient titles I refer to Liddell, Scott and Jones.

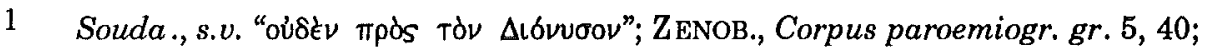
Plut., Moralia I, 1, 615a. Cf. A.W. PICKARD-CAMBrIdge, Dithyramb, Tragedy and Comedy, rev. T.B.L. WEBSTER, Oxford, $1977^{2}$, p. 166-168; A. LESKY, Die tragische Dichtung der Hellenen, Göttingen, 1972, p. 42 sq.

2 See A. TAтTi, Le Dionysalexandros de Cratinos, in Métis, 1 (1986), p. 325-332, on the Dionysalexandros of Kratinos. H. Jeanmaine, Dionysos. Histoire du culte de Bacchus, Paris, 1951, p. 330 sq., counts 20 out of 600 drama titles with a Dionysiac theme. C.A.P. RUCK, The Wild and the Cultivated: Wine in Euripides' Bacchae, in R.G. WASSON, S. KRAMRISH, J. OTT, C.A.P. RUCK (eds.), Persephone's Quest: Entheogens and the Origin of Religion, New HavenLondon, 1986, p. 220, argument that "it is difficult to see how constant, simple repetition of the Dionysus myth would not have become unbearably tedious", does not hold, of course, compare our never tedious sermons, passion-plays, and icons presenting the life of Christ. 
question of this relationship has been a neglected one ${ }^{3}$, while the studies on drama continue to disregard the cultic aspect. Whether the question has been forgotten or avoided, is not easy to discern, but one reason may be our professional compartmentalising and specialisation that causes historians of religion to shun the domain of drama and historians of literature to beware of religion. I will address the problem, however, asking what connection existed between the cult of Dionysos and drama, other than simply and solely the formal one. In the course of this investigation I will examine all aspects of Dionysos in order to reach some common divisor to the multiple forms of his cult. My conclusion is that this essence can be summed up in the expression creative euphoria. I will subject the phenomena of the Dionysos cult to a comparative analysis, drawing on anthropological theory, particularly the work of Victor Turner. In doing so, Ancient theatre will cease to cause a problem, and its specific nature will appear to fit well into the complex of Dionysiac cult activity.

\section{Approaches to the problem}

The dearth of investigations into the question of Dionysos' relationship with the theatre may be due to its associations with Nietzsche's Die Geburt der Tragödie. The answers to the question like those provided by Ridgeway, Dieterich, Harrison, Murray, or Nilsson earlier this century do not seem to further investigation either. Those who are no longer inspired by ideas of a heros cult and fertility demon rites, goat skin dancers, or by the eniautos daimon and his passion, nor by laments for the dead ancestors, will find few alternatives ${ }^{4}$.

3 As is noticed by S.D. Goldhill, Anthropologie, idéologie et les Grandes Dionysies, in P. Ghiron-Bistagne, B. Schouler (eds.), Anthropologie et théâtre antique, CGITA, 3 (1987), p. 55-74, 55. J.J. WINKLER, F.I. ZEITLIN (eds.), Nothing to Do with Dionysos? Athenian Drama in its Social Context, Princeton, 1990, does not address the essence of the question. J.-P. VERNANT, "Le dieu de la fiction tragique", in J.-P. VERNANT, P. VIDAL-NAQUET, Mythe et tragédie en Grèce ancienne, II. Paris 1986, 17-24, addresses it briefly.

4 W. RIDGEWAY, The Origin of Tragedy with Special Reference to the Greek Tragedians, Cambridge, 1910; A. DiETERICH, Die Entstehung der Tragödie, in $A R W$ (1908), p. 163-196; J.E. HARRISON, Prolegomena to the Study of Greek Religion, Cambridge, $1908^{2}$; G. MURRAY, Excursus on the Ritual Forms Preserved in Greek Tragedy, in J. HARRISON, Themis, Cambridge, 1912, p. 341-363; M.P. N ILSSON, Der Ursprung der Tragödie, in Neue Jhrb. für klass. Wiss. $(1911)=$ Opuscula Selecta I, Lund, 1951, p. 61-145. Cf. JEANMAIRE, op. 
However, in more recent discussions of Dionysos few scholars make serious attempts at integrating the phenomenon of the theatre into their interpretation of the cult. Often the topic is left out ${ }^{5}$, sometimes drama (especially Euripides' Bakkhai) is adduced to offer source material ${ }^{6}$, and at most interpretations of the role of the theatre are vague and impressionistic ${ }^{7}$. Otto suggests that the god manifests himself in tragedy in an immense excitement, revealing the "Doppelheit" of life and death symbolised in the mask. Jeanmaire fits drama into a general picture of a cult of purification, healing and intitiation, referred to as mania. And Daraki proposes that drama is "...l'enfant né de l'union d'une orthodoxie et d'une hétérodoxie", that is, Dionysiac cult being part of civic religion offers heterodox thought couched in cultic drama ${ }^{8}$. Taplin and Winkler accept that Attic drama has "nothing to do with Dionysos"9. Among more comprehensive attempts at defining the

cit. (n. 2), p. 321 sq.; G.F. Else, The Origin and Early Form of Greek Tragedy, Cambridge, Mass, 1967 (Martin Class. Lect., 20), p. 26 sq.

5 E.g. W.K.C. GuTHRIE, "Dionysos", in The Greeks and Their Gods, London, 1977, p. 145-182; L. GERNET, A. BOULANGER, Le génie grec dans la religion, Paris, $1970^{2}$, p. 97-129, notes 440-443; A. HenRICHs, Greek and Roman Glimpses of Dionysos, in C. Houser (ed.), Dionysos and his Circle. Ancient through Modern, Harvard University, Cambridge, Mass, 1980 (The Fogg Art Museum), p. 1-11; A. HenRICHs, Changing Dionysiac Identities, in B.F. MEYER, E.P. SANDERS (eds.), Jewish and Christian Self-Definition, III, London, 1982 (Self-Definition in the Graeco-Roman World), p. 137-160, 213-236; A. HENRICHS, Loss of Self, Suffering, Violence: The Modern View of Dionysos from Nietzsche to Girard, in HSPh, 88 (1984), p. 205-240.

6 For example E.R. Donns, The Greeks and the Irrational, Berkeley, Calif., 1951 (Sather Class. Lect., 25), Appendix I; GuTHRIE, op. cit. (n. 5), p. 147 sq.

7 W.F. OTTO, Dionysos, Mythos und Kultus, Frankfurt, 1933 (Frankfurter Studien zur Religion und Kultur der Antike, 4); JEANMAIRE, op. cit. (n. 2). Cf. L. GERnET, Anthropologie de la Grèce ancienne, Préface J.-P. VERnANT, Paris, 1968, p. 63-89, p. 71 sq.; E. Simon, Die Götter der Griechen, München, 1969, p. 279; M. DaraKI, Dionysos, Paris, 1985, p. 232 sq., uses a biological metaphor for describing tragedy as a "un fait de mutation".

8 OTTO 1933, op. cit. (n. 7), p. 194, followed by K. KERÉnYI, Dionysos und das Tragische in der Antigone, Frankfurt, 1935 (Frankfurter Studien zur Religion und Kultur der Antike, 13); JEANMAIRE, op. cit. (n. 2), p. 311; DARAKI, op. cit. (n. 7), p. 16.

9 O. TAPLIN, Greek Tragedy in Action, London, 1978, p. 162; J.J. WINKLER, The Ephebes' Song; Tragoidia and Polis, in Representations, 11 (1985), p. 26-62 = J.J. WINKLER, F.I. ZEITLIN (eds.), op. cit. (n. 3), p. 20-62, 51. 
relationship between drama and cult is the work of Burkert. He conceives of tragedy within a general theory of sacrifice, the masquerade responding to a primeval human need for collective abreaction of guilt. But sacrifice is held at other gods' rites and involves other animals than goats as well. Lesky points to the connection between Dionysiac ecstacy and "die 'Ergriffenheit' des primitiven Dämonenspielers"10.

We are, of course, informed by Aristotle that drama evolved out of traditions of dithyramb and phallic song (Arist., Po., 1449a 7-15), but explanations of this kind remain exterior. Historical studies, telling where a tradition originated, do not exhaust the question why a phenomenon took on a particular form ${ }^{11}$. In addition to the genetic explanation stressing a chronological course of events, I will give due attention to a functional explanation. I conceive of the concept in a wide sense. In my opinion it is precisely this dimension that has been neglected.

A recent attempt at interpreting the function of tragic drama within a social context has been made by John Winkler. He offers the theory that the chorus of tragedy consisted of ephebes, which suggests that the performances were part of an initiation programme ${ }^{12}$. Interesting as it is, the theory does not consider the relationship between theatre and Dionysos' cult in general nor does Winkler account for the overall role of drama in society.

We have to proceed along the lines of social science and a double investigation in diachronic and a synchronic perspectives. We need a comparative approach all the more so in view of the general bewilderment at the many and mutually incompatible aspects of the cult of Dionysos. Jane Harrison already commented: "Dionysos is a difficult god to understand"13. Guthrie thinks: "The worship of

10 W. BURKERT, Greek Tragedy and Sacrificial Ritual, in GRBS, 7 (1966), p. 106, 112 sq.; LESKY 1972, op. cit. (n. 1), p. 42.

11 DARAKI, op. cit. (n. 7), suggests an inquiry into the early history of cult and theatre. ELSE, op. cit. (n. 4), p. 7, 31, dismisses the search for a functional connection between theatre and cult, and attributes the development of tragedy to a few creative personalities.

12 W INKLER, art. cit. (n. 9), p. 28 sq., 44.

13 HARRISON 1908, op. cit. (n. 4), p. 364. 
Dionysos...can never be wholly explained"14. Erika Simon cites Hölderlin: "Nah ist und schwer zu fassen der Gott"15. Scholars frequently apply the characteristic "paradox" or "contradiction"16. Even experts as Burkert thinks the god "mysterious and incomprehensible"17, and Henrichs sums up the agreement of "most students" of the god: "Dionysus defies definition"18.

The problem with finding some core in the manifold manifestations of Dionysos cult may be due to their utter strangeness. We meet intoxication, raving maenads, and phallic processions. From a puritan's point of view it would be a provocation to call this "God". In spite of this seemingly insuperable diversity of cult aspects I think it worth wile, pace Henrichs ${ }^{19}$, to search for some coherence. After all, the Greeks themselves denominated these diverse phenomena with a single term: Dionysos. At the level of concrete cult expressions and beliefs the god may appear a collection of disparate entities. At a more abstract level, a deity of the Greek universe may well have corresponded to some unified force ${ }^{20}$. I agree with Sourvinou-Inwood who argues that we

14 GUTHRIE, op. cit. (n. 5), p. 145.

15 Simon, op. cit. (n. 7), p. 269.

16 OTTO, op. cit. (n. 7), p. 111; GERNET, BOULANGER, op. cit. (n. 5), p. 104; DARAKI, op. cit. (n. 7), p. 11; HENRICHS 1980, art. cit. (n. 5), p. 3; J.-P. VERNANT, Conclusion, in J.-P. VERNANT (éd.), L'Association dionysiaque dans les sociétés anciennes, Actes de la table ronde organisée par l'École française de Rome 2425 mai 1984, Rome, 1986 (Coll. de l'École française de Rome, 89), p. 292; cf. H.S. Versnel, "EI $\Sigma$ IONY $\Sigma O \Sigma$. The Tragic Paradox of the Bacchae", in Inconsistencies in Greek and Roman Religion I. Ter unus: Isis, Dionysos, Hermes. Three Studies in Henotheism, Leiden, 1990 (Studies in Greek and Roman religion, 6), p. 96-205.

17 W. BuRKert, Greek Religion. Archaic and Classical, transl. J. Raffan, Oxford, 1985, p. 167.

18 HENRICHS 1984, art. cit. (n. 5), p. 209. Similarly VERNANT, art. cit. (n. 16), p. 291.

19 HeNRICHS 1980, art. cit. (n. 5), p. 5.

20 Similar attempts at finding unity beneath the multifarious aspects of a deity are J.-P. VERNANT, La société des dieux, in Mythe et société en Grèce ancienne, Paris, 1974, p. 103-120 and J.D. MIKALSON, Athenian Popular Religion, Chapel Hill-London, 1983, p. 68 sq. on Zeus, J. Bremmer, "Effigies Dei" in Ancient Greece: Poseidon, in D. VAN DER PlAS (ed.), Effigies Dei. Essays on the History of Religions, Leiden, 1987 (Studies in the History of Religions . Numen. Suppl. 
should not extrapolate a deity's personality from one local cult to another. However, I will mostly keep to the cult manifestations in Athens.

Dionysos has been provoking to modern researchers due to his strangeness. According to McGinty it is for this reason that the chapter on Dionysos in Greek culture has always been written on the basis of scholars' unconscious notions about what is truly Greek and 'thus' human ${ }^{21}$. Therefore, some have stressed that Dionysos was an immigrant from the east or the north, representing a cult the Hellenes in the last sought to keep at arm's length ${ }^{22}$. A cult, according to von Wilamowitz, they never would have admitted into their society, if not women had forced it through, irrational as they are ${ }^{23}$. Or the god is assumed to belong to a pre-Hellenic or lower class strata of the population ${ }^{24}$. Rohde saw Dionysos as a foreigner, but gradually "hellenisirt und humanisirt". Guthrie, too, emphasises the Hellenes' ability to tame this irrational force ${ }^{25}$. The majority stuck to the idea of a foreign god, and those who accepted the Hellenic origin of Dionysos, Otto and Dodds, were scholars who recognised religious ardour and irrationality as genuine human forces 26 .

51), p. 35-41, on Poseidon, and H.S. Versnel, Apollo and Mars One Hundred Year after Roscher, in Visible Religion, 4-5 (1985-86), p. 134-172 on Apollo.

21 P. MCGINTY, Interpretation and Dionysos. Method in the Study of a God, The Hague-Paris-New York, 1978 (Religion and Reason, 16), Introd. Cf. HENRICHS 1984, art. cit. (n. 5).

22 M.P. NiLsson, Geschichte der griechischen Religion. 2 Bde. Apollon I p. 529564, Dionysos I p. 564-603 + 611-615, München, 1967, p. 564 sq., 578. Still A. PiatKowski, La signification du culte dionysiaque dans les régimes de l'ancienne tyrannie, in J. HaRmaTTA (ed.), Actes VIIe Congrès FIEC, Budapest, 1984, I p. 73-75. The god's foreign status is, of course, part of Dionysiac belief, and this aspect is to be noted, see M. DeTIENNE, Dionysos en ses parousies. Un dieu épidémique, in Association (n. 16), p. 57.

23 U. von W ILAMOWITZ-MoELLENDORFF, Der Glaube der Hellenen (Auflage von 1955) 2 Bde., Darmstadt, 1956, II, p. 66. Cf. M.P. NILSson, Greek Popular Religion, New York, 1940, p. 95.

WILAMOWITZ 1956, op. cit.(n. 23), II, p. 71.

25 E. RoHDE, Psyche, Seelencult und Unsterblichkeitsglaube der Griechen. 2 Bde., Tübingen, 1910, II, p. 44; GUTHRIE, op. cit. (n. 5), p. 172 sq.

OTTO, op. cit. (n. 7), p. 21, 32 sq.; DoDDs, op. cit. (n. 6), ch. III. 
Since the Mycenaean origin 27 and the aristocratic element ${ }^{28}$ of Dionysos are well attested, we should make efforts to understand his cult as part of the Greek religious system. We are well advised not to conceive of Dionysos' cult as just some magic manipulation of the forces of fertility ${ }^{29}$, or as a pre-scientific way of explaining the laws of nature ${ }^{30}$. Ritual act and belief may well be something else than an infantile mode of acting or an outdated way of thinking. Nor should we have recourse to some primitive mentality in need of manifesting itself in orgiastic expressions ${ }^{31}$. Supposing some primitive mentality we separate ourselves from some radically foreign and primitive, that is, unintelligible phenomenon. The myths of the resistance against Dionysos should not be taken at face value, as historical record ${ }^{32}$. And the images of religious abandonment are no psychiatrical report ${ }^{33}$.

Interpretations of Dionysos, as compared with other deities, have been particularly prolific. Whatever approach to Dionysos is chosen,

27 BuRkERT, op. cit. (n. 17), p. 162; B.C. DIETRICH, The Origins of Greek Religion, Berlin-New York, 1974, p. 176. For the tree cult manifestation see LIMC, III, 1, p. 414; B. RUTKowsKI, Der Baumkult in der Ägäis, in Visible Religion, 3 (1984), p. 159-171, 163; SIMON 1969, op. cit. (n. 7), p. 270.

28 G.A. Privitera, Dioniso in Omero e nella poesia greca arcaica, Roma, 1970, p. 144, 150; VERNANT 1986, art. cit. (n. 16) p. 298; H.A. ShapIRo, Art and Cult under the Tyrants in Athens, Mainz a/ Rhein, 1989, p. 92, connects Dionysos with a middle-class in Fifth-century Athens. For Dionysos participating in the battle between Olympians and Giants in the Archaic age see F. VIAN, La guerre des géants. Le mythe avant l'époque hellénistique, Paris, 1952, p. 83-90; H. Hoffmann, Ten Centuries that Shaped the West, Mainz, 1970 (Greek and Roman Art in Texas Collections), p. 378 sq., ill. 175d sq.; T.H. CARPENTER, Dionysian Imagery in Archaic Greek Art. Its Development in Black-Figure Vase Painting, Oxford, 1986 (Oxford Monographs in Class. Arch.), ch. 4.

29 Early HARRISON 1908, op. cit. (n. 4), p. IX; NILSSON, op. cit. (n. 22), I p. 582, L. SÉChan, P. LÉvÊQUe, Les grandes divinités de la Grèce, Paris, 1966, p. 289.

30 Nilsson, op. cit. , I p. 37 sq., 50 sq.

31 Wilamowitz, op. cit. (n. 23), II p. 60 sq., N ILSSON, op. cit., I p. 568.

32 WILAMOWITZ, op. cit. , II p. 65.

33 Pace DoDDs, op. cit. (n. 6), p. 75 sq. Nor are we to imagine Dionysiac worship as an evolutionary stage towards a more developed religious relationship with God, as is sometimes assumed. Cf. JEANMAIRE, op. cit. (n. 2), p. 8; U. B IANCHI, La religione greca, Torino, 1975, p. 44 sq. 
however, the starting point usually is the individual ${ }^{34}$, with exception of (the later) Jane Harrison, who, influenced by Durkheim, recognised the collective nature of Dionysiac enthousiasm "...by the common excitement, they [the members of a group] become emotionally one, a true congregation..." 35 . It will become apparent that I adhere to this line of interpretation, and I think interpretations that see nothing but the experience and expressions of a single human being are bound to run aground. The motive for individuals to congregate in an ecstatic cult is not just their need "to escape the harsh realities of life"36. There is more to human life than the experience of the 'self' and to drama than expression of the individual's emotions, guilt, and view of life.

Generally scholars have grown more cautious in presenting broad syntheses, though the urge to do so is strong; Even those who think Dionysos defies definition, assume the essence of duality, ambiguity or opposition ${ }^{37}$. However, instead of focusing on either term of an opposition, we should recognise the fact that Dionysos comprises both terms, that is, transcends the division ${ }^{38}$. The nature of Dionysos, then, has been subjected to a wide range of interpretations, none of which I think completely satisfying. In the next section I will present a theoretical framework for interpreting the god's manifestations aiming at a comprehensive view of the various cults and at offering an explanation for Dionysos' epiphany in drama.

34 RUCK, art. cit. (n. 2), p. 223, discussing the effects of drama on the spectators claims that the performance "...reunited the individual with the primordial and darker versions of the self that underlay the persona of civilized life, the infant in the adult and the wild in the cultured."

35 J.E. HARRISON, Themis. A Study of the Social Origins of Greek Religion, Cambridge, 1912, p. 45.

36 HENRICHS 1982, art. cit. (n. 5), p. 140. Cf. HENRICHS 1980, art. cit. (n. 5), p. 3; HENRICHS 1984, art. cit. (n. 5), p. 209. Asklepios being a god of healing, whose ministrations were personal, assembled no organised religious group. This may indicate that the god saw to the well-being of the individual, physically and psychologically, helping "to shape the 'life world' of the seeker" (H.C. KEE, Self-Definition in the Asclepius Cult, in B.F. MEYER, E.P. SAUNDERS (eds.), op. cit. (n. 5), p. 119). The fact that the cult of Asklepios was associated with Dionysos may suggest a division of tasks between the two deities, and indicate that the last did not direct himself primarily to the individual.

37 HENRICHS 1984, art. cit. (n. 5), p. 239 sq.

38 This is noticed by Maria DARAKI, op. cit. (n. 7), p. 31. sq., 34 sq. Dionysos crosses the boundaries between life and death through the liquid element. 


\section{Theoretical framework}

In view of our knowledge of the organisation and participation at Ancient theatre performances there are strong reasons for starting from the collective perspective ${ }^{39}$. One should realise that every group, apart from its basic needs of organising production and reproduction, is in need of some means to create themselves as a group. Suggesting that festivals primarily respond to this last-mentioned need, I think it necessary to study the properties of these activities, and the way they are embedded in society ${ }^{40}$. A group is not something naturally given, but has to be created in a continuous process. In all groups arrangements are made in order to reach this result, and psychological processes of a specific kind are involved. During these arrangements, which aim at other than productive and practical ends, the group renews its culture, the devices for doing this being many and varied. Within anthropological theory the totality of these activities, rituals, myths and icons, is referred to as "symbolism" 41 . These phenomena share some properties due to the fact that they do not belong to logical and empirical thinking, our ability of describing and explaining the world. They create the cultural world, this area that essentially cannot be verified because its truths are arbitrary ${ }^{42}$. All groups feel, however, the urge to

39 Only few do so, but see DARAKI, op. cit., p. 9 sq. (following Gernet) and O. DE CAZANove, De quelques théories modernes sur l'association dionysiaque, see Association (n. 16), p. 6 sq.

40 That there may be some connection between the structure of a given society and the nature of its festivals, is suggested by D. HANDELMAN, Reflexivity in Festival and Other Cultural Events, in M. Douglas (ed.), Essays in the Sociology of Perception, London, 1982, p. 162-190.

41 R.F. Spencer (ed.), Forms of Symbolic Action. Proc. of the 1969 Annual spring meeting of the American ethnological soc. Seattle, London, 1969, p. 325. especially the introduction by V.W. TURNER (p. 3-15) and the discussion by M. S piro (p. 208-214), V.W. Turner, "Liminal" to "Liminoid", in Play, Flow and Ritual: An Essay in Comparative Symbology, in Process, Performance \& Pilgrimage, New Delhi, 1979 (Ranchi anthropology series, 1), p. 11-59; R.A. SHWEDER, Anthropology's Romantic Rebellion Against the Enlightenment, or There's More to Thinking than Reason and Evidence, in R.A. Shweder, R.A. Levine (eds.), Cultural Theory: Essays on Mind, Self and Emotion, Cambridge, 1984, p. 27-66.

42 SHWEDER, art. cit. (n. 41) p. 38, 43 sq. 
anchor these truths somewhere, and generally they do so by referring to a metaphysical realm 43 .

Symbolic phenomena tend to be 'impressive' and apt at anchoring the values of our culture in our nervous system. This has been particularly thoroughly studied by Victor Turner, but other investigations stress this aspect as well ${ }^{44}$. Sally Moore and Barbara Myerhoff observe that celebrations tend to offer some "presentational" item, a dramatisation of some kind, and add that this has to be presentational: When the truth is conveyed in a series of concrete events, this will deflect discussion ${ }^{45}$. The kind of truths that are concerned here, of course, belong to the most fundamental and revered of the group, who is not prepared to offer them for criticism 46 .

Victor Turner has observed that many rituals offer a bewildering array of exotic elements, drama, masks, dress, rhythm, music, dancing, alcohol and incense, and stresses that these modes of behaviour are not to be ascribed to the primitivity of the group adopting them. These phenomena are necessarily 'exotic', affecting the senses, emotions, and phantasy of the participants. In addition, the events that are dramatised are generally of a dramatic kind: Birth, death, blood, sexuality and similar emotionally laden subjects. The whole arrangement aims at creating an awe-inspiring experience in order to satisfy the group's need for a celebration ${ }^{47}$. This awe, furthermore may be modulated in varying moods, in accordance with the programme of the celebration, from gravity to hilarity, even when metaphysical

43 SHwEDER, art. cit. (n. 41).

44 See for example V.W. TuRNER, Symbols in Ndembu Ritual, in The Forest of Symbols. Aspects of Ndembu Ritual, Ithaca-New York-London, 1967 [1974], p. 19-47; ID., Dramas, Fields and Metaphors. Symbolic Action in Human Society, Ithaca-New York, 1974; ID., op. cit. (n. 41); R.G. D'ANDRADE, Cultural Meaning Systems, in R.A. SHWEDER, R.A. LEVINE (eds.), op. cit. (n. 41), p. 88119.

45 S.F. MoORE, B.G. MYerhofF (eds.), Secular Ritual, Assen-Amsterdam, 1977, Introduction.

46 For a distinction between the "undiscutable" realm and the realm of debate, see P. B OURDIEU, Esquisse d'une théorie de la pratique, Paris, $1972=$ Outline of a Theory of Practice, transl. R. Nice, Cambridge, 1977 (Cambr. Stud. in Soc. Anthrop., 16), p. 168.

47 TURNER 1967 [1974], op. cit. (n. 44), p. 27 sq.; TURNER 1974, op. cit. (n. 44), p. $55 \mathrm{sq}$. 
powers are concerned. Bruce Kapferer has studied such behaviour, and underscores that deities that are being ridiculed during a mockery sequence are highly revered outside that part of the programme ${ }^{48}$. Handelman observes that precisely in a society where the metaphysical order is well established, people can afford mocking their superhuman powers 49 .

This last-mentioned phenomenon reminds us of the fact that symbolic arrangements are circumscribed by boundaries of time and place, a "sacred space-time" in the terminology of Victor and Edith Turner ${ }^{50}$. These boundaries are marked with behaviour that signalises transition, so creating a tripartite structure, corresponding to Van Gennep's rites of passage. Schøjdt outlines a pattern of separation, liminality, and reaggregation for celebrations generally 51 . Groups tend to establish some regular recurring of the event, hence the notion of a "seasonal ritual". The most important aspect with these rituals is their collective character. It is not the individual (youth)'s transition to some new status that is involved, it is the community departing from everyday business to a celebration and vice versa in order to renew its existence. The complex theatre festival in Athens does not seem to involve the status transition of the ephebes but rather constitute a seasonal ritual of the whole community. Central to the arrangement is the staging of "dramata" which bring the primordial creators of the cultural order back to the present. These heroes stride to action frequently transgressing the moral order of society 52 . Such a dramatisation of primordial time should not be confused with factual

48 B. KAPFERER, The Ritual Process and the Problem of Reflexivity in Sinhalese Demon Exorcisms, in J.J. MACA loon (ed.), Rite, Drama, Festival, Spectacle, Philadelphia, 1984, p. 179-207. We may consider the role of Dionysos in Aristophanes' Batrakhoi in this perspective. Moreover, celebrations need not refer to any metaphysical power to be "ritual" in character, see MOORE, MYERHOFF, op. cit. (n. 45), p. 19 sq.

49 HANDELMAN, art. cit. (n. 40), p. 172.

50 V.W. Turner and E. Turner, Religious Celebrations, in V. Turner (ed.), Celebration. Studies in Festivity and Ritual, Washington, DC, 1982, p. 202.

51 A. VAN G ENNEP, Les rites de passage (1909) = The Rites of Passage, transl. M.B. Vizedom, G.L. Caffee, London, 1969; J.P. SchøJdT, Initiation and the Classification of Rituals, in Temenos, 22 (1986), p. 93-106.

52 TURNER and TURNER, art. cit. (n. 50), p. 202 sq. For a more detailed discussion see DES BouvrIE 1990, op. cit. (n. *), p. 70 sq. 
prehistory ${ }^{53}$. Victor and Edith Turner observe that during the liminal phase at these celebrations a general dissolution of the normal order occurs, an "anti-structure", frequently combined with a "ludic recombination" of the elements of culture.

Turner and Turner discuss some properties of this liminality. Often parts of the human body, for example the phallos, are magnified and exhibited, provoking laughter. This laughter seems to contribute to the loosening of bonds and thus promoting the ritual creativity in the congregation. According to Victor Turner, people act in this way in order to renew their culture, not just slavishly prolongating the past, but reordering, readjusting, and re-creating the present ${ }^{54}$. A well known phenomenon in symbolic expressions is inversion, the establishment of a world upside-down or mundus inversus 55 .

The "ludic" renewal of the community, it seems, should be seen as a collective process, in contrast to modern intellectual criticism, which is exercised by some few and most often remains without consequence. In view of these words of caution we should beware of interpreting theatre primarily as the critical voices, that is, intellectual activity, of its poets, and rather recognise the symbolic character of the performance as a whole ${ }^{56}$. It is Victor Turner's important contribution to this field of

53 J.B REMMER, What is a Greek Myth?, in J. BREMMER (ed.), Interpretations of Greek Mythology, London-Sydney, 1987, p. 1-9, 3, supposes that myths should be really old in order to be traditional. MOORE and MYERHOFF (op. cit. n. 45), p. 7 argue that rituals involve "traditionalising" techniques suggesting the antiquity of the performance.

54 TURner and TURner, art. cit. (n. 50), p. 203; V.W. Turner, Frame, Flow and Reflection: Ritual and Drama as Public Liminality, in TURNer 1979, op. cit. (n. 41), p. 94-120, 111.

55 See B.A. BABCOCK (ed.), The Reversible World. Symbolic Inversion in Art and Society, Ithaca-London, 1978; H. KENNER, Das Phänomen der verkehrten Welt in der griechisch-römischen Antike, Klagenfort, 1970 (Aus Forschung und Kunst, 8).

56 Victor Turner suggests that the group reflects on its culture criticising the present state of affairs (e.g. TURNeR and TURNER 1982, art. cit. (n. 50), p. 205). However, it has been doubted whether this reflection is conscious in all respects. It seems rather to be the observing anthropologist projecting his/her reactions to the course of events with an attitude of detachment due to her/his cultural distance and critical awareness of the arbitrariness of culture, a risk they are warned by Kapferer and Crick of committing, KAPFERER, art. cit. (n. 48), p. 203. Cf. M.R. CRICK, Anthropology of Knowledge, in Annual Review of Anthropology, 11 (1982), p. 287-313, 292 sq. 
study to have drawn attention to the non-rational aspects of symbolic behaviour. In his extensive work on drama world over he underscores the importance of emotional, sensory, and imaginational stimulation. As has been referred to earlier, in the liminal phase all senses are brought into a state of excitement, while the performance communicates some message that is fundamental to the existence of the community. In this way the sensory receptivity of the human being is connected with the cognitive faculty so as to create a fusion between the two, creating a "love of duty"57. It is important to realise that he conceives of this learning process as going on at an unconscious level of the mind. This is the reason why the process is couched in all kinds of 'exotic' media affecting the whole body. This structuring of the group in common creation involves, then, the individual as well, who is in need of some collective world order for the sake of structuring the self 58 .

In view of Freud's analysis of the so-called primary processes and recent investigation into the human faculty of intuition the imaginative and emotional nature of symbolic phenomena as well as their preverbal mode of communication becomes comprehensible ${ }^{59}$. The psychological and physiological processes that are involved in collective ritual, have been studied in an interdisciplinary study that confirms Turner's assumptions ${ }^{60}$.

Central in the culture process is the need to create a sense of "oneness". The group gathering in order to create its world, that is, its culture, establishes a spirit of collectivity. This sense of "group unity" can be registered in different intensities, and entails a deminished consciousness of hierarchy. Such a phenomenon is arrived at in group interaction synchronising the minds of the participants. These processes are studied by physiologists who have registered the precise

57 TURNER 1967 [1974], op. cit. (n. 44), p. 27 sq.; ID. 1974, op. cit. (n. 44), p. 55 sq.

58 A. CoHen, Symbolic Action and the Structure of the Self, in I. LEwIS (ed.), Symbols and Sentiments, London, 1977, p. 117-128.

59 S. FREUd, Die Traumdeutung, Leipzig-Wien, 1900; T. BASTICK, Intuition. How We Think and Act, Chichester-New York, 1982.

60 E.G. D'Aquili, C.D. LAughlin Jr., J. Mc Manus (eds.), The Spectrum of Ritual. A Biogenetic Structural Analysis, New York, 1979, reviewed in V.W. TURNer, The New Neurosociology. in E.L.B. TuRNER (ed.), On the Edge of the Bush. Anthropology as Experience, Tuczon-Arizona, 1985, p. 275-289. For some details see below. Cf. DES BouvRIE 1990, op. cit. (n. *), ch. III. 
physical reactions involved ${ }^{61}$. In Turner and Turner's terms it is labelled "communitas...in most preindustrial societies communitas is not sought as an end in itself, but is treated as a means of purifying, redefining and revitalizing a social structure"62. In this shared euphoria feelings of structure are reduced while anti-structure prevails.

\section{The theatre festivals as "seasonal ritual"}

Having outlined some fundamental properties of symbolic phenomena, I think it is beyond doubt that the theatre festivals of Dionysos are to be classified as "seasonal rituals"63.

This Dionysiac dance form developed gradually, in Athens culminating in the institution of the official tragic chorus about 537 . In iconography this moment marks a change in the way Dionysos was presented, "from symbol of wine" to "an extremely complicated mythic personality" 64 . Through the theatre medium the participants were exposed to a visual and auditory performance, with its costumes, masks, music and dance. The drama festival modulated the moods of the participants according to its prescribed stages, from prayer, to dithyrambic song to comedy and tragedy ${ }^{65}$. The drama created an image of mythical events, activating phantasy, thought and emotions with its exciting mythical plot. This "presentational" multi-media performance engaged the collective of citizens. Even if only some, the actors, were engaged in the performance, the audience participated equally in reviving the primordial past, celebrating the larger-than-life actions of the heroic race ${ }^{66}$.

Yearly during some six days the community congregated in the temenos of the god, separating themselves from the profane world with

61 B. Lex, The Neurobiology of Ritual Trance; see E.G. D'AQUILI, C.D. LAUGHLIN Jr., J. MCMANUS (eds.), op. cit.(n. 60), p. 117-151.

62 TURNER and TURNER, art. cit. (n. 50), p. 206.

63 Contrary to WINKLER, art. cit. (n. 9), p. 2 sq.

64 CARPENTER, op. cit. (n. 28), p. 29.

65 Cf. KAPFERER, art. cit. (n. 48), p. 202 sq.

66 KAPFERER, art. cit.(n. 48), p. 186 sq.; SCHøJDT, art. cit. (n. 51), p. 97, 103. 
processions and sacrifice ${ }^{67}$. We are maybe not informed about its details. The procession with the god's image from 'Eleutherai' (the Akademeia) transfers the setting to remote days, when the god entered the community, while the purification demarcated the area of the celebration. No doubt the wearing of garlands and other festive behaviour contributed to setting the arrangement off from everyday occupations and in altering the minds of the celebrants. A noteworthy part of the programme is the $\kappa \omega \hat{\omega} \mu s^{68}$, encouraging an emotional release from every-day bonds and constrictions in a ritual period of licence. At the City Dionysia at least the gathering of the $\epsilon_{\kappa \kappa} \lambda \eta \sigma_{\alpha} \alpha$ after the performances seems to serve as a rite of reaggregation 69 . Being the god of wine Dionysos demanded that alcohol was consumed during the Dionysia 70 . There are indications that even incense was burnt of Phrygian $\sigma \tau u ́ p a \xi$, a kind that carried oriental connotations and was applied in religious and medical contexts 71 .

All these elements suggest that the City Dionysia were a celebration during which the Athenian community recreated its existence, reactivating the forces of the past in tragic myth and playing joyfully with the present in comedy.

Having argued for the ritual nature of Dionysos' theatre festivals, we have still to answer the question why these festivals were attributed to this particular god. There are numerous celebrations that show some of the same properties that qualify for the term. He shares his nature as a deity of vegetation with Demeter, being accompanied by the Horai ${ }^{72}$. His cult is not even the only one to include dancing, masking and choral song ${ }^{73}$. The only domains where Dionysos seems to have a

67 For the details of the celebrations see L. DEUBNER, Attische Feste, Hildesheim, $1969^{2}$, p. 123 sq., 138 sq.; H.W. PARKe, Festivals of the Athenians, London, 1977, p. 104 sq., 125 sq.

68 PARKE, op. cit. (n. 67), p. 128.

69 PARKe, op. cit. (n. 67), p. 135 sq.

70 Plato, Lg., 637 a-b (Athen., 4, 156a), 775b; Philochoros, 328 F 171 Jacoby = ATHEN., 11, 464f.

71 AtHen., 14, 626f. Cf. P. FAURe, Les parfums de la Grèce, in C. MossÉ (éd.), La Grèce ancienne, Paris, 1986, p. 175-188, 180.

72 Burkert, op. cit. (n. 17), p. 222; PHILOCHOROs, 328 F 5b Jacoby.

73 Among other cults using masks are Artemis, BURKERT, op. cit. (n. 17), p. 103 sq., 151 n. $21,223$. 
monopoly are wine, maenadism and the theatre. I will consider these aspects hoping to reach some coherence in the variety of cult forms.

\section{Wine}

Dionysos appears as the god of wine early in literary and iconographical form, in Homer, Hesiod and on the oldest black figure vases ${ }^{74}$. Being thus associated with a plant Dionysos has naturally been conceived of as a fertility cult ${ }^{75}$. However, his festivals do not coincide with the main periods of activity in viticulture ${ }^{76}$. We should be reminded of the fact that, when a belief relates a god to some aspect of nature, culture is always involved 77 . Wine should not be seen, then, as vegetation or as nourishment, but as a special gift of the god. His festivals are celebrations of consumption rather than cultivation, and in his (male) cult the consumption of wine is central. It is referred to as $\gamma$ duvos, meaning liquid, but also glory, joy, Erquickung. According to Jeanmaire the expression means "humidite vivifiante" 78 . Wine is so powerful a liquid that it was only Dionysos who managed to bring back Hephaistos to Olympos, the other gods, even Ares, being incapable in this task $^{79}$. Daraki fails to notice this, and suggests that Dionysos crosses boundaries between life and death by way of the liquid element, wine being one specimen of the kind ${ }^{80}$. It is not this minor physical property that makes wine a powerful gift, it is its intoxicating effect. Comparing Dionysos' gift to the significance of alcohol in other cultures, there is no reason for surprise. The tendency to consecrate the means of

74 H. Hom. Bacch., 35, (HoM., Il., 14, 325); Hes., Op., 11-14; Th., 941; B URKERT, op. cit. (n. 17), p. 161, cf. 281 sq.; CARPENTER, op. cit. (n. 28), p. 1 sq.

75 The emphasis on fertility or vegetation is widespread, see for example HENRICHS 1982, art. cit. (n. 5), p. 148.

76 A minor festival, the Oskhophoria, was associated with the grape harvest, DEUBNER, op. cit. (n. 67), p. 146.

77 M. Douglas, Introduction to Grid/Group Analysis, in M. Douglas (ed.), op. cit. (n. 40), p. 7.

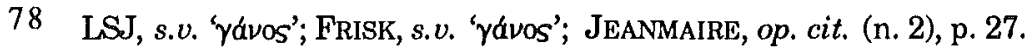

79 CARPENTER, op. cit. (n. 28), p. 13 sq.,

80 M. DARAKI, La mer dionysiaque, in $R H R$, 199 (1982), p. 3-22, p. 10, "le vin comme une version de T'élément liquide". 
intoxication is widespread, and equally universal is the tendency to surround its consumption with elaborate rules and restrictions ${ }^{81}$.

Dionysos' gift of wine was distributed at the symposion, and at the Anthesteria. At this celebration (male?) children received their first $\chi$ oûs and were introduced into social life. Coming of age they were admitted to adult society in the symposion. During both occasions drinking was regulated, as was its consumption in general ${ }^{82}$, and women were excluded from this domain 83 . The curious customs at the second day of the Anthesteria, with the participants drinking at separate tables and in silence, are to be interpreted in terms of an inversion confirming the norm. Wine was to be consumed in commensality and drinking was accompanied by speech and song, that is, potentially symbolic means ${ }^{84}$.

Plato's defence of wine in the Laws (637a sq.) may mirror the Athenian attitude to wine ${ }^{85}$. Accepting its consumption as a means of making people supple and pliant to the forces of acculturation,

81 For literature on the subject see for example D.G. MANDELBAUM et al., Alcohol and Culture, with CA Comment, in Current Anthropology, 6, (1965), p. 281294; W. Younger, Gods, Men, and Wine, New York-London, 1966; M.K. BaCoN, Cross-Cultural Studies of Drinking: Integrated Drinking and Sex Differences in the Use of Alcoholic Beverages, p. 23-33, and H. B ARRY, CrossCultural Evidence That Dependency Conflict Motivates Drunkenness, in M.W. EvereTT et al. (eds.), Cross-Cultural Approaches to the Study of Alcohol, The Hague, 1976, p. 249-263 .

82 Plato, Lg., 671a; Solon (D.L. I 57); Alexis, Aesopos fr. II 299 Kock/690 Meineke (ATHEN., 10, 431d-e).

83 HenRICHS 1982, art. cit. (n. 5), p. 139; F. GRAF, Milch, Honig und Wein. Zum Verständnis der Libation im griechischen Ritual, in Perennitas. Studi in onore di Angelo Brelich, Roma, 1980, p. 216. In view of this I still wonder whether girls received their $\chi 0$ s. PHILOSTR., Her., 12, 2. (187, 20 Kayser) mentions of

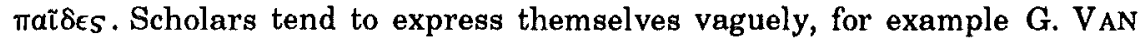
HoORN, Choes and Anthesteria, Leiden, 1951; G. RAEPSAET, C. D ECOCQ, Deux regards sur l'enfance athénienne à l'époque classique. Images funéraires et choes, in LEC, 55 (1987), p. 3-15; M.-C. VIllaNUEVA PUIG, La ménade, la vigne et le vin. Sur quelques types de représentations dans la céramique attique des VIe et Ve siècles, in REA, 90 (1988), p. 35-64, 52 sq., emphasises that while maenads are handling wine in iconography, they are never depicted drinking.

84 Plato, Lg., 775b. DeUBNER, op. cit. (n. 67), p. 93 sq.

85 For due appreciation of the passage see E. BELFIORE, Wine and Catharsis of the Emotions in Plato's Laws, in CQ, 36 (1986), p. 421-437. See PARKE, op. cit. (n. 67), p. 131. 


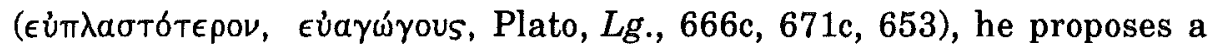
general programme for song and dancing under the guidance of Apollo, the Muses and Dionysos (653d, 665a sq.) in order to bring the souls into the desired rhythm and harmony. In anthropological literature the social function of drinking is generally acknowledged ${ }^{86}$. The physiological and psychological properties of alcohol have conducted to its widespread use in ritual gatherings, being an artefact integrating the individual in society. Its effects seem to be to create a sense of selfreliance and independence as well as a the sense of belonging to the group. Not infrequently drinking is related to games of chance, that may be interpreted as a need for assertiveness. At the symposion ќ́ттаßоs was played ${ }^{87}$. So tightly connected are society and drinking, that is seems to be possible to surmise changes in social structure from the changes in drinking customs ${ }^{88}$.

If alcoholic intoxication is so important a social phenomenon, it should not surprise us that it was consecrated as the gift from Dionysos. Nor that its use was subject to restricive elaboration ${ }^{89}$. This intoxication, strengthening social bonds within the group as well as the self, no wonder was felt to be a divine force. We should, then, conceive of wine primarily as a social force instead of a means of nutrition or delight. In myth the mixture of wine is a more important civilising act

86 See for example MANDElBaum, art. cit. (n. 81), p. 281 sq.; the articles by BARRY and BACON, art. cit. (n. 81); M. Douglas, A Distinctive Anthropological Perspective, in M. Douglas (ed.), Constructive Drinking. Perspectives on Drink from Anthropology, Cambridge-Paris 1987, p. 4.

87 ATHEN., 10, 427d; P. VON DER MÜHLL, Das griechische Symposium, Basler Vortrag 23.11.1926. Schweiz. Beitr. zur Altertumswiss., 12 = XENOPHON, Das Gastmahl. Rowolts Klassiker der Literatur und der Wissenschaft Heft 7, Berlin, 1957, p. 79-109, 94 sq. = Ausgewälte kleine Schriften, B. Wyss (hrsg.), Basel, 1975, p. 483-505, 493 sq.; W.J. SLATER, Symposium at Sea, in $H S P h, 80$ (1976), p. 161-177; BARRY, art. cit. (n. 81), p. 261.

88 BARRY, art. cit. (n. 81), p. 261 sq.; MANDELBAUM, art. cit. (n. 81), p. 281 sq.

89 A.P. MCKINLAY, Bacchus as Healthgiver, in Quarterly Journal of Studies on Alcohol, 11 (1950), p. 230-246; ID., Attic Temperance, ibid, 12 (1951), p. 61-102; Younger, op. cit. (n. 81); G. HAGENow, Aus dem Weingarten der Antike. Der Wein in Dichtung, Brauchtum und Alltag, Mainz a/Rhein, 1982 (Kulturgesch. d. antiken Welt, 12); D.E. GERBER, The Measure of Bacchus. Euenus fr. 2 West, Gent. - Pr. $=$ Ant. Pal. 11. 49, in Mnemosyne, 41 (1988), p. 39-45; Mandelbaum, art. cit. (n. 81), p. 283, refers to the opposition between Dionysos and Apollo. 
than its cultivation, witness the myths of Amphiktuon or Melampous 90 . It was after having learnt to mix wine and water that people were able to go upright ${ }^{91}$. The lack of wine is a characteristic of different "Randvolken" or of the Golden Age, that is, pre-civilisation"2. The habit of drinking wine unmixed is considered a sign of barbary attributed to barbaroi, Scyths, satyrs, kentaurs and kyklopes, and kentaurs or women, while lusting after wine, cannot withstand its effects ${ }^{93}$.

The strict order of drinking at the symposion under the guidance of a symposiarch as well as the customs of prayer and the wearing of garlands and libation are also indications of the ritual nature of wine $e^{94}$. The habit of starting with a libation of unmixed wine is interpreted by Graf as a rite of separation into the marginal phase ${ }^{95}$. The commensality of the symposion no doubt promoted the solidarity of the participants in bonds of $\phi\left(\lambda l \alpha^{96}\right.$. In Olympia Dionysos was united in

90 PhILOChoros, 328 F 5b Jacoby; StAPHYLOS, 269 F 7 Jacoby = ATHEN., 2, 45cd. M.J. Miller, The Athenian Autochthonous Heroes From the Classical to the Hellenistic Period, diss. Harvard 1983, Univ. Microfilms, Ann Arbor, 1989.

91 Xenophanes, fr. 1 and 5 D-K; Theogn., fr. 477 sq. (Loeb); Archil., fr. 120 W.; Alcaios, fr. Z 22 L.-P.; AnACReon, 64 P.; Athen., 5, 179e, 138c-; 2, 45d; 10, 430a sq.; PLIN., NH 7, 199; cf. P. VILLARD, Le mélange et ses problèmes, in REA, 90 (1988), p. 19-33; Phanodemos, 385 F 12 Jacoby = Athen., 11, 465a.

92 GRAF, art. cit. (n. 83), p. 214 sq.

93 Herod ., 6, 84; Athen., 10, 427a; Plato, Lg ., 637d-e; Athen., 11, 476b-c; 10, 427c; Hom., Od., 9, 205, 360; Eur., Cycl., 452 sq., 149; Hygin, Fab., 125; PIND., fr. 44, 46; ARISTOPH., Equ., 87; ApOllod., I, 5; Diod., 4, 70; HygIN., Fab., 33; ARISTOPH., Ec., 227; Lys ., 200-235; Th., 735; cf. ATHEN., 10, 429a-b.

94 Athen., 10, 425a-e; Plato, Lg., 671c; von DER MÜhll, op. cit. (n. 87), M. BLECH, Studien zum Kranz bei den Griechen, Berlin-New York, 1982 ( $R G V V, 38)$, p. 63 sq.

95 Graf, art. cit. (n. 83), p. 219. Athen., 15, 693.; Philochoros, 328 F 5A-b Jacoby; cf. HAGENOW, op. cit. (n. 89), p. 39 sq.; B URKERT, op. cit. (n. 17), p. 70 sq.

96 It might be suggested that this explains why the cult image of Zeus Philios in Megalopolis was shaped "as Dionysos", with a drinking bowl. PAUs., 8, 31, 4. O. Murray, Symposion and Männerbund, in Proc. of the 16th Intern. Eirene Confer. Prague, 31.8-4.9 1982 Vol. 1 (1982), p. 47-52; ID., The Symposion as Social Organisation, in R. HÄGG (ed.), The Greek Renaissance of the Eight Century B.C. Tradition and Innovation. Proc. of the Second Intern. Sympos. at the Swedish Inst. in Athens, Stockholm, 1983 (Skrifter utg. Svenska inst. $i$ Athen 4, 30), and ID. (ed.), Sympotica. A Symposium on the Symposion, Oxford, 1990; P. SCHMITT, A. SCHNAPP, Image et société en Grece ancienne: les 
cult with the Xáptтєs ${ }^{97}$, daughters of Zeus and Eurunome. Xenophanes invokes two of them in his poem on the symposion. Their names are transmitted differently, but they refer to the joy of festivity Thaleia, Aglaia, Euphrosune (festivity, splendour, merriment, so Hes., Th., 907 sq. $)^{98}$.

Dionysos is connected with the Horai, Thaleia, Karpo and Auxo (plenty, fruitfulness, increase) too, the forces of the seasons, of regular ripening and vitality 99 . The Anthesteria in Athens seem to have anchored the regular ordering of social life in nature, in the renewal and blossoming of spring-time. The joy and delight of wine was celebrated as a force creating the community through the ritual of an inverted symposion, the inversion implying the normal order of a 'mouth-to mouth' communion with shared cups and shared speech ${ }^{100}$. During the same festival Dionysos as a force in marriage was invoked through the hieros gamos ritual. The new generation (of boys) was accepted into the community in the xoûs rite. And eventually the group of the deceased kin were incorporated into the festival. An inscription describing the four major stages in the life of a (male) citizen mentions

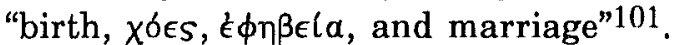

The Anthesteria thus created a communion synchronically between the living (young and adult males?) and diachronically between the living and the dead (males?) in a general celebration of the renewal of the generations through marriage ${ }^{102}$. In addition the myth of Orestes arriving for (the first) trial at the Areiopagos celebrated the

représentations de la chasse et du banquet, in $R A$ (1982), p. 57-74; P. ScHMITTPANTEL, Banquet et cité greque. Quelques questions suscitées par les recherches récentes, in $M E F R, 97,1$ (1985), p. 135-158.

97 C.R. LoNG, The Twelve Gods of Greece and Rome, Leiden, 1987 (EPRO, 107), T $13 \mathrm{~B}$, p. 58 sq.

98 Xenophanes, fr. 1 D-K.; H. Oranje, Euripides' Bacchae. The Play and Its Audience, Leiden, 1984 (Mnemosyne Suppl., 78), p. 103-113 sq. "sacred character of eixpooúm"; HoM., Il., 3, 246; Od., 9, 6; PIND., O. 14; EPHOROS, $70 \mathrm{~F}$ 152 Jacoby; PAUS., 9, 35, 1.

99 PhILOCHOROs, 328 F 5b Jacoby; DARAKI, op. cit. (n. 7), p. 45 sq.

100 CALlim., fr. 178 Pfeiffer; vON DER MÜHLl op. cit. (n. 87).

101 IG II/III, 1368,130.

102 E.C. KEULs, Male-Female Interaction in Fifth-Century Dionysiac Ritual as Shown in Attic Vase Painting, in Male and Female in Greek Cult, ZPE, 55 (1984), p. 287-297. 
establishment of law and order in society. On the whole this Dionysiac festival can be characterised as a kind of New Year's Beginning, involving different kinds of reversal and suspension of the normal social order ${ }^{103}$.

\section{Maenadism}

Like alcohol dance is a crucial social institution and universally connected with social processes. It may serve a number of functions and several of them may operate at the same time. A specialist in the field, Paul Spencer presents a catalogue of the principal functions of dance, among which are a "socialising" function, a "cathartic" function and "self-generation" bringing the dancers into a "state of exaltation"104. There is also the function of "ritual drama", which Spencer relates to the theory of Victor Turner. In the light of these findings I will consider both maenadism and drama respectively and relate any findings to the conclusions on the role of wine in Dionysiac cult. I suggest that maenadism could be seen especially under the perspective of both cathartic dance and dance of self-generation, "building up a ceremonial climax" in ecstacy. Spencer emphasises that the atmosphere is intensified by the interaction between the participants, describing this type of dance as an "act of communion".

In a study on the physiology of ritual Barbara Lex refers to the specific processes that are going on in ritual trance. Participating in a musical and dancing group the members are stimulated into a profoundly collective experience. Their repetitive acts, the rhythmic stimuli and the fixed interaction tend to produce states of trance entailing extraordinary behaviour and resulting in unusual feats of endurance ${ }^{105}$. The stimulants that are particularly appropriate to this effect are percussion instruments, hand-clapping, rhythmical chanting and dancing, but also light effects. In the end the participants will experience hallucinations and an "oceanic feeling" followed by

103 W. Burkert, Homo Necans. The Anthropology of Greek Sacrificial Ritual and Myth, transl. P. Bing., Berkeley, Calif., 1983, p. 213-243; J. BREMMER, The Early Greek Concept of the Soul, Princeton, 1987, p. 108 sq.

104 P. Spencer, Introduction, in P. SPENCER (ed.), Society and the Dance. The Social Anthropology of Process and Performance, Cambridge, 1985.

105 LEX, art. cit. (n. 61), p. 120 sq. 
complete exhaustion and immobility ${ }^{106}$. Lex relates these exceptional feelings to the special abilities of the right hemisphere of the brain. In particular the responses to temperature in trance are subject to "reversal phenomena", cold is experienced as heat and vice versa ${ }^{107}$.

An important condition for ritual trance is the collective participation and the result of shared emotional stimulation will be an experience of "oneness". Far from being any pathological state ceremonial possession will have integrating effects on individual and group ${ }^{108}$. It is to be noted that d'Aquili and Laughlin observe that this experience of "oneness" occurs in varying grades of intensity, from a complete state of trance to mild forms of a sense of communion ${ }^{109}$. Thus they seem to confirm Victor Turner's assumptions of "communitas"110.

Maenadic rites of a kind corresponding to the processes outlined by Lex and d'Aquili and Laughlin may have been wide-spread ${ }^{111}$. The fact that the details of the cult are poorly known may be related to the circumstance that the ritual was heavily surrounded by myth. Presumably some of its effects were presicely due to its esoteric nature,

106 E.G. D'Aquili, C.D. LAUGHLin Jr., The Neurobiology of Myth and Ritual, see D'AQUili, LAUGHLIN Jr., McManus (eds.,) op. cit. (n. 60), p. 152-182, 176 sq. LEX, art. cit., p. 15, 128.

107 LEX, art. cit., p. 126 sq. For an exhaustive account of the complex processes in brain and nervous systems see the entire article.

108 LEX, art. cit., p. 138 sq.

109 D'Aquili, LAUGHLin Jr., art. cit. (n. 106), p. 158 sq.

110 TURNER 1979, art. cit. (n. 41), p. 40.

111 A. HenRICHS, Greek Maenadism from Olympias to Messalina, in HSPh, 82 (1978), p. 121-160; R. KRAEMER, Ecstacy and Possession: The Attraction of Women to the Cult of Dionysos, in HThR, 72 (1979), p. 55-80, 73; J. BREMMER, Greek Maenadism Reconsidered, in ZPE, 55 (1984), p. 267-286, 286; Delphi: M.-C. VillanUeVa-PUIG, À propos des Thyiades de Delphes, see Association (n. 16), p. 31-51; Arkadia: M. Jost, Sanctuaires et cultes d'Arcadie, Paris, 1985 (Ecole française d'Athènes. Etudes Péloponnésiennes, 9), p. 421, 425-438; Ionia: F. GRAF, Nordionische Kulte. Religionsgeschichtliche und epigrafische Untersuchungen zu den Kulten von Chios, Erythrai, Klazomenai und Phokaia, Roma, 1985 (Bibliotheca Helvetica Romana, 21), p. 77, 293 sq.; Boiotia: A. SCHACHTER, Cults of Boiotia Acheloos to Hera, London, 1981 (BICS, Suppl., 38, 1), p. 173, 179 sq., 183 sq., 188; Argos: W. BuRKerT, op. cit. (n. 17), p. 168 sq.; Korinth: R. LISLE, The Cults of Corinth, diss. John Hopkins Univ., Baltimore, 1955, p. 19 sq.; Lakonia: S. WIDE, Lakonische Kulte, Leipzig, 1893, p. 162 sq., 170. 
stimulating the imagination of potential participants with myths of mystery ${ }^{112}$. In addition the fact that presumably only some women partook in the rites representing all women, may have led these cult acts to remain shrouded in mystery, in order that all women might feel engaged in some exceedingly sublime contact with the god ${ }^{113}$. It seems to be a regular feature of possession rites that participants are selected for being especially prone to 'madness' (or in need of ritual rebellion) 114 .

Euripides' portrayal of the Bákxal is considered by Versnel as "recognisable to the audience"115. Their wild raving and murderous behaviour was no doubt part of mythical elaboration conveying a complex of fantasies about participation in the rites. Imagery on vases of maenads having intercourse with satyrs combine with this picture of canibalistic females roaming in the wild forests that seems to be familiar from ethnographic accounts ${ }^{116}$. Euripides presents the women reaching a state of trance through dancing and the use of rhythmic instruments. Seen in this light it seems probable that the drama offers a view of both what was going on in ritual as of its mythical elaborations, based on exaggeration of ritual practice. According to Annie Bélis this drama, as well as other sources, mention specific instruments belonging to Dionysiac cult that all provoke "la démesure et du dérèglement, du vacarme et de la frénésie"117. And Marie DelavaudRoux has come to the conclusion on basis of the Bakkhai and of iconographic material that the dances "permettent de parvenir à l'extase

112 I think B REMMER, art. cit. (n. 111), p. 275 is correct in stressing that myths of maenadism tell an exagerated tale of what was going on in the rites.

113 BREMMER's objections, art. cit., p. 285, to the notion voiced by KRAEMER, art. cit. (n. 111), p. 73, that the cult addressed itself to "deprived" women, seem to be based on a misunderstanding. Even if females of the élite participated, these were deprived in terms of formal power in relation to men. See also I.M. LEwIs, Religion in Context. Cults and Charisma, Cambridge, 1986, p. 39, 43.

114 HENRICHS 1982, art. cit. (n. 5), p. 143 sq.

115 H.S. Versnel, Pentheus en Dionysos. Religieuze achtergronden en perspectieven, in Lampas, 9 (1976), p. 8-41- 17; cf. SoPH ., OT., 209; Ant., 1150 sq.

116 LEWIS, op. cit. (n.113), p. 28, 56.

117 A. BÉLIS, Musique et transe dans le cortège dionysiaque, in P. GHIRoNBistagne (éd.), Transe et théâtre, Actes de la Table Ronde Internationale Montpellier 3-5 mars 1988, Montpellier, 1989, p. 23. 
mystique par l'intermédiaire de toute une série de mouvements destinés à provoquer vertige et état de transe"118.

As has been rightly pointed out by Henrichs, maenadism is a women's cult as the symposion and wine belongs to males ${ }^{119}$. It seems clear that women engaged in these rites of reversal during a period when they were paricularly excluded from arenas of formal power. According to Lewis possession rites like maenadism are dynamic events that contribute to maintaining the power balance in a social group 120 .

The fact that the cult seems to include male participants does not contradict this. It may well have been that the women were conducted into and out of their "sacred space-time" by a male cult leader (diviner,

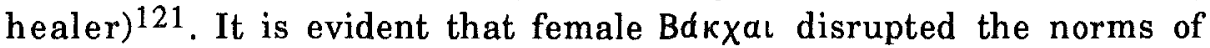
female social order, leaving home and roaming in the wild borderlands between nature and culture. Being an integral element of Greek religious life Dionysos is still consistently presented as a foreigner ${ }^{122}$, coming from the East ${ }^{123}$ or North ${ }^{124}$. His iconography may underscore this 'fact', since the god may wear the oriental $\xi \pi \epsilon \nu \delta v^{\prime} \eta s^{125}$. This seems to be a technique of disclaiming responsibility for a cult that involves elements that are looked upon unfavourably elsewhere in social life, corresponding to classifications as "superstitious survivals"126.

118 M.-H. Delavaud-Roux, Danse et transe. La danse au service du culte de Dionysos dans l'antiquité grecque. Approche et méthode de reconstitution, see GHIRON-BistaGne (éd.), op. cit. (n. 117), p. 37.

119 HENRICHS 1982, art. cit. (n. 5), p. 139 sq.

120 LEwIS, op. cit. (n. 113), p. 40 sq.

121 Lewis, op. cit., p. 27, 44 sq., 57. I.M. LEwIs, Ecstatic Religion. A Study of Shamanism and Spirit Possesion, New York-London, 1989²; KRAEMER, art. cit. (n. 111), p. 72. The entire plot of the Bakkhai opposes the idea that males could be ordinary participants of maenadic rites.

122 Eur., $B a$., 642.

123 Eur., Ba., 12-20, etc.; M. Detienne, Dionysos en ses parousies. Un dieu épidémique, see Association (n. 16), p. 53-83; cf. F. GRAF, Women, War and Warlike Divinities, in ZPE, 55 (1984), p. 245-254, 252.

124 EuR., Ba., 569.

125 M.C. Miller, The Ependytes in Classical Athens, in Hesperia, 57 (1989), p. 313-329, 315.

126 Lewis, op. cit. (n. 113), Preface. 
The maenadic rituals, with their $\omega \mu \circ \phi a \gamma l \alpha^{127}$ suggest particularly the liminal nature of Dionysos, an aspect that is signalised in numerous contexts. In vase iconography the god is presented en face, a sign of marginality, according to Frontisi-Ducroux. The universe of satyrs is characterised as "un univers d'inversion" by Lissarague 128 . Likewise the habit of dressing as a female, both by Dionysos and his $\kappa \omega \hat{\mu} \mathrm{S}_{\mathrm{S}}$ is a sign of liminality, his role as the creator of a mundus inversus, as has been discussed by Hedwig Kenner ${ }^{129}$.

\section{Dionysiac drama}

Recapitulating our question of the relationship between Dionysos' cult and the theatre we should consider the nature of Ancient drama. Earlier I have argued on the basis of Aristotle's Poetics that tragedy is to be considered as a medium for the community to renew its sense of cultural values. During these performances emotions of shock and outrage were roused, as a reaction upon the disruption of fundamental social institutions. Not every act of violence roused tragic emotions, according to Aristotle. Only in case the persons confronting each other were $\phi\left(\lambda o l\right.$, the reactions of $\xi \lambda \epsilon o s$ and $\phi \dot{b} \beta \beta_{0 S}$ (immediate reactions like "shock and horror") were roused. The notion of a $\mu \alpha \rho \tau(\alpha$, commonly referred to as "the tragic fault", can, then, be understood as Aristotle's intuition of what was going on in tragic drama: a disruption of the social order. Aristotle's concept of dvarvóptors implies the acknowledgement of social norms and obligations, particularly those of $\phi \iota \lambda(\alpha$. Within this perspective $\kappa a ́ \theta a \rho \sigma \iota s$ can be understood as a sense of order, a security that the horrible events on stage do not affect the divinely established social world ${ }^{130}$. Tragedy presented a recognisable universe, a $\mu l \mu \eta \sigma s$, but beyond that it aimed at effecting an emotional disturbance in the audience, which was generally acknowledged in Antiquity. Tragic drama was obviously a symbol rousing shock and

127 W. BuRKert, in M. ELIADE (ed.), Encyclopedia of Religion, Vol. XI, New YorkLondon, 1987, p. 70-73, s.v. 'omophagia'.

128 F. Frontisi-Ducroux, La mort en face, in Métis, 1 (1986), p. 197-217, ill. I-IV 204; F. LISSARAgUe, Pourquoi les satyres sont-ils bons à montrer?, in Anthropologie et thêâtre antique, op. cit. (n. 3), p. 93-106, 99.

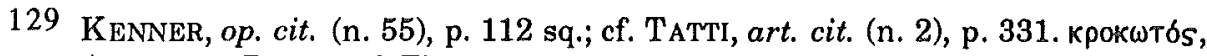
ARISTOPH., Ra., 45; cf. Th., 253.

130 S. DEs BouvrIe, Aristotle's Poetics and the Subject of Tragedy, in Arethusa, 21 (1988), p. 62 sq. 
sorrow complementary to comic drama aiming at laughter. In tragedy the normal order of the world was inverted, presenting a disruption of the oikos (and polis) institution with its relationships and norms. Some members or roles may be missing, the patrilineal succession may be blocked, the chastity of the wife may be threatened and similar disruptions. The community participated through this symbol in a collective revitalising of these values. By being exposed to a powerful presentation implying an inversion of basic institutions the audience was renewed in its sense of the 'natural' order, the basic institutions of oikos and polis ${ }^{131}$. Plato once ( $L g ., 838$ a) comments on the way social order is maintained, suggesting that basic rules, like the incest prohibition, not are enforced by written law but by way of oral communication, "in drama".

Dana Sutton has noticed that satyr drama presents a plot involving an anxiety-provoking course of events ${ }^{132}$. The world order, while threatened, is preserved, and the (sympathetic) characters are rescued. This seems to confirm my hypothesis on tragic drama: Satyr drama presents the less than realistic satyr chorus and the comic elements of physical urges and intriguing. Satyr plays may have represented a gentle landing after the serious and disturbing action in tragedy ${ }^{133}$.

Comic drama presented another form of inversion of the world order, aiming at provoking laughter. Laughter being a very complicated phenomenon, it may have intellectual and emotional sources, as well as a purely creative aspect. Intellectual reactions at an incongruence, at finding the order of things inverted, recognise its normal state. Emotional sources of laughter may involve a revolt, aggressive laughter threatening moral and social values, or corrective aggression against social deviance ridiculing these very challenges. And comic laughter may originate from our sense of freedom, a celebration of our creative potential ${ }^{134}$. It is likely that Old Attic comedy with its wild animal fantasies included all these varying reactions at different moments. Its plots present frequently an inversion of the

131 For a detailed discussion of these aspects of tragedy (with interpretation of single dramas) I refer to DES B OUVRIE 1990, op. cit. (n. *).

132 D.F. SuTton, The Greek Satyr Play, Meisenheim am Glan, 1980 (Beiträge zur klass. Philol., 90), p. 126, 129.

133 D.J. ConACHer, Euripidean Drama. Myth, Theme and Structure, Toronto 1967, p. 333 sq.; SUTTON, op. cit. , p. 181 sq.

134 See for example W.D. HowarTh (ed.), Comic Drama, London, 1978. 
social order, as do the women's comedies, staging an inverted hierachy of the sexes, or the Batrakhoi, inverting the hierarchy of master and slave. The topsy-turvy events of Old Comedy imply a suspension of physical and social laws during the hilaric phase of the drama festival ${ }^{135}$.

These fantasies were relegated to the comic phase of Dionysos' festival. It seems possible that this phase corresponds to the "ludic" aspects of seasonal rituals as described by Turner and Turner, and were the locus for critical readjustment in the social realm. Both aggressive laughter at too powerful or deviant members of the community and liberating laughter that deny the threatening realities may have occurred, but Attic comedy was hardly the carneval revolt of the underprivileged.

A prominent aspect of comic drama are its obscenities. The focus on genital humor seems to have been due to ritual licence, it was not part of ordinary behaviour. This humor, as well as the general prominence of phallic symbols in Dionysos' cult, may be interpreted, not as a reminiscence of some earlier fertility ritual ${ }^{136}$, but as a device for liberating the community from their profane experience and introducing them into the creative liminal phase of the ritual. In his discussion of obscenities in Old Comedy Henderson refers a theory according to which obscenities effect a regression to an infantile experience of liberty before the personality was tamed and forced into civilisation by authorities prohibiting obscene expression. Obscenity is thus "a powerful weapon by which to defy civilisation and the adult way of perceiving the world"137. During the comic phase, the audience was thus reintroduced into the unordered state of the mind promoting creative thinking.

We may, then, conclude that the drama complex was a liminal phenomenon ordered in different phases, aiming at different emotional reactions. Tragedy presented a dramatised myth bringing primordial time to the present, or rather blurring the distinction between past and present. It offered an image of concrete events, it aimed at reactions of

135 For a useful discussion of the workings of comedy see K. MCLEISH, The Theatre of Aristophanes, London, 1980.

136 HeNRICHS 1982 , art. cit. (n. 5), p. 148 "the natural conditions of human reproduction".

137 J. Henderson, The Maculate Muse. Obscene Language in Attic Comedy, New Haven-London, 1975, p. 37. Contrast BURKERT, op. cit. (n. 103), p. 58 sq. 
shock and outrage provoked by a disrupted social order, in short, tragedy presented "sacra" in Turner and Turner's sense, while satyr drama brought the audience down after a demanding and disturbing experience of disorder. Comedy seems to have corresponded to Turner and Turner's "ludic recombination" 138 with its grotesque and grossly obscene elements and an action based upon a world upside down ${ }^{139}$, suspending the physical and social order.

Abstracting further, I would suggest that the theatre festival introduced several forms of inversion engaging the community in emotional concentration and excitement to creative ends. After the great procession a $\kappa \omega \mu$ os was held ${ }^{140}$ which shaked the participants out of their profane experience while entering the liminal world of Dionysos. While comedy created a liberating atmosphere of carnaval, suspending the world order, tragedy aimed at the opposite, it provoked reactions of 'cultural horror' at seeing the world order threatened or disrupted, thus charging that order with new value.

\section{Apollo and Dionysos}

At this point it is natural to inquire into the relationship between Dionysos and Apollo. Their close brotherhood goes back to an earlier date than Nietzsche's theory. In cult and iconography the two often figure together, if not directly in myth. As an example may serve the Kerch krater in Leningrad (St. 1807) where Dionysos and Apollo meet in front of a palm tree ${ }^{141}$. Their cults are frequently intertwined in Athens as well as in other communities ${ }^{142}$.

Henrichs mentions that Dionysos did not have a Panhellenic shrine ${ }^{143}$. At Delos and Delphi, however, the two shared the

138 TuRNER and TURNER, art. cit. (n. 50), p. 202 sq., 204 sq. See above the section on theoretic assumptions.

139 KENNER, op. cit. (n. 55).

140 PARKE, op. cit. (n. 67), p. 128.

141 See E. Simon, Festivals of Attica. An Archaeological Commentary, Wisconsin, 1983, ill. 27.

142 NILSSON, op. cit. (n. 22), p. 573; SIMON, op. cit. (n. 7), p. 292; BURKERT, op. cit. (n. 17), p. 223 sq.; SimON, op. cit. (n. 141), p. 89. At Thebes, PAUS., 4, 27, 6; Detienne, art. cit. (n. 123), p. 67; SCHACHTER, op. cit. (n. 111), p. 185 sq. At Phlya and Myrrhinous, PaUs., 1. 31, 4.

143 Henrichs 1982, art. cit. (n. 5), p. 151. 
responsibility for the sacred domain and in Hellenistic times they appeared each on a pediment of the temple at Delphi ${ }^{144}$. Ploutarchos (De $E$ apud Delphos, 389c) tells us that Apollo left Delphi to Dionysos during the winter months ${ }^{145}$. This distribution of responsibility for the calendar involves the gods' epiphany at fixed times of the year. Both 'arrive' at the appointed moment of the year ${ }^{146}$. Such a distribution corresponds, however, with mental spaces dividing the universe in Apollonian and Dionysiac realms ${ }^{147}$. Bourdieu has given attention to the fact that there is a tendency among preliterate groups to shape their culture by interweaving the categories of culture and the facts of nature as experienced by the body ${ }^{148}$. Even in Athens there seems to have been some distribution between Apollonian and Dionysiac phases of the year ${ }^{149}$. Both gods are central to the cultural creative process. Their epiphany mark a transition between cosmic forces. Plato considers the two together in the Laws, celebrating their beneficent gifts of festivals and dance (Plato, Lg., 653c, 665a, $672 \mathrm{~d}-\mathrm{e})^{150}$.

In a thought-provoking article Versnel offers a synthesis of the cult phenomena of Apollo ${ }^{151}$. His interpretation must have consequences for our interpretation of the Dionysos phenomena. According to Versnel, the essence of Apollo is an ordering force. His cult is primarily organised around the transition rites of ephebes. Apollo protects the marginal phase, that is, the borderline between childhood and adult hoplite status. According to Versnel Apollo is familiar with "the outer world" and boundaries as well as with the centre, the $\delta \mu \phi a \lambda \delta s$ of the world and the middle of the polis at the agora. Because of this double attention he may

144 Delos, Simon, op. cit. (n. 7), p. 292. AESCHYL., fr. 341; EUR., fr. 477 Nauck $^{2}$. Delphi, Paus., 10, 19, 4.

145 PARKE, op. cit. (n. 67), p. 103.

146 DetienNe, art. cit. (n. 123), p. 57, stressing that Dionysos' epiphany is his essence oversees that Apollo likewise has his advent, a fact emphasised by VERSNEL, art. cit. (n. 20), p. 138.

147 DARAKI, op. cit. (n. 7), p. 31.

148 BOURDIEU, op. cit. (n. 46), p. 89 sq.

149 DEUBNER, op. cit. (n. 67), p. 125. The dadoukhos bade the community invoke the god at the Lenaia. K. KERÉNYI, Dionysos, Urbild des unverstörbaren Lebens, München, Wien, 1976, p. 231, 236.

150 See Mandelbaum, art. cit. (n. 81), p. 283.

151 VERSNEL, art. cit. (n. 20). 
seem a complex deity, but the essence is of the god's power is his world ordering force. This essence explains his role as leader of new and faraway settlements (ámoเk $(\alpha)$ ). The young men who are sent out into "the outer world" are guided precisely by Apollo. As a ordering force Apollo controlls periods of time, places and transitions where dissolution and wilderness threatens. He is responsible for civilised life defending it against the forces of chaos, as a purifier he maintains law and order in the world. I would suggest that his responsibility for order and boundaries explains the expressions $\mu \eta \delta \dot{\epsilon} \nu \not \partial \gamma \alpha \nu$ and $\gamma \nu \omega \theta \mathrm{c}$ бєаuтóv: "Do not transgress the boundaries creating social order" and "Know thy place in the social order". As an edifying guarator of order he

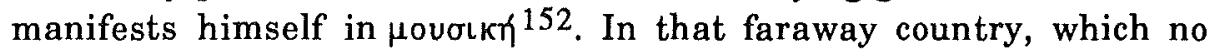
mortal can reach by land or by sea, Apollo meets the Hyperboreans, a people situated between gods and men, who are cognate to those living in Elysion (Pind., P. 10, 27). They are "selige"153, righteous and blessed, and the god strengthens himself in their company for his divine ordering task.

\section{Conclusion}

Dionysos seems to be one of the liminal forces of the Greek world. But unlike e.g. Artemis, he is not connected with the transition from childhood to adult status. In Athens the festival of the Anthesteria celebrated the gift of wine and recreated the social order of marriage and law. It congregated the family in groups of the new members, its adult males and its deceased members in table communion, thus affirming patrilineal kinship order. The maenadic rites inverted and reestablished the hierarchy between male and female. The theatre festival likewise assembled the Athenian polis. The ritual engaged all segments of the citizen population, but particularly those with active civic rights, the adult male mo $\lambda$ ( $\tau$ col. During the festival the audience was affected with tragic horror and comic laughter. The normal world was inverted within the sacred space-time of the ritual exposing the audience to an attack on its cultural feelings of normality. After the performances the emotional storm calmed and society reverted to its

152 Athen., 14, 628a, citing Philochoros, draws attention to the difference between Dionysiac and Apollonian behaviour in offering drinkofferings to these gods.

153 Nilsson, op. cit. (n. 22), p. 548; BURKERT, op. cit. (n. 17), p. 146; RE s.v. 'Hyperboreer'. HERoD., 4, 32 sq. 
normal state. In its effect these dramatic processes contributed to infusing its audience with a sense of the basic order of the world.

In the face of these facts we should classify the theatre festival as well as the other festivals as seasonal rituals ${ }^{154}$. Dionysos' cult manifestations gathered groups or the whole citizenship, his apparition was accompanied by dissolution. Plato welcomes Dionysos' gifts of wine and dance, which loose our limbs and make us more pliant. The

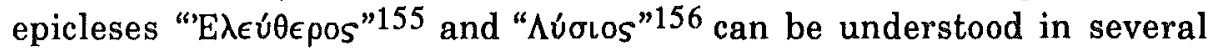
ways: As a physical liberation from prohibitions and constraints in the individual, and as a dissolution of social order ${ }^{157}$. Dionysos cults may involve myths of madness. Madness being an extreme consequence of the individual's loss of a sense of 'reality', is an expressive image for the collective dissolution of social order, that is, for the liminal process. This dissolution is accompanied by reversals and inversion ${ }^{158}$.

If Dionysos is the force of the process of dissolution, of the temporary destruction of social boundaries, Apollo is the force restructuring those boundaries. For that reason, Dionysos has to be contented with figuring in Apollo's shade. The god supervising the boundaries and categories in the world gives at times way to the god obliterating these boundaries, in order to revitalise society and its hierarchies. Apollo abhors pollution, the blurring of boundaries, Dionysos welcomes this very blurring of categories in an continuous process of rebirth. The forces of Dionysos and Apollo alternate in ruling the social world. Dionysos 'comes from the East', from barbarian people admitting uncontrolled emotionality. Apollo arrives from the righteous Hyperboreans ordering the world with controlled sensibility. They meet in the centres of the world, Delphi and Delos.

154 There is thus no reason to call the theatre festival an initiation as WINKLER, art. cit. (n. 9), proposes.

155 Hesych., s. $v$. 'E $\lambda \epsilon \in \hat{\theta} \theta \epsilon \rho S^{\prime}$ '.

156 Paus., 2, 7, 5 sq. (Sikyon), 2, 2, 6 sq. (Korinth), 9, 16, 6 (Thebes). GraF, op. cit.

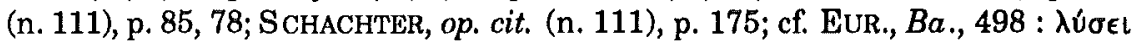
$\mu \epsilon \delta \delta a l \mu \omega \nu$.

157 GRAF, op. cit. (n. 111), p. 78, 87; TURNER and TURNER, art. cit. (n. 50), p. 205 sq.; SPENCER, op. cit. (n. 104), p. 27 sq.

158 GRAF, op. cit. (n. 111), p. 84 sq.; KENNER, op. cit. (n. 55), p. 112-132; DARAKI, op. cit. (n. 7), p. 9 sq. Dionysos seems to be "a god without language" according to HENRICHS 1982, art. cit. (n. 5), p. 155. His cult is accompanied by cries and images. 
It is not suprising, then, that Dionysos frequently is classified as a polis god. At Lesbos, Khios, Patrai, Naxos, Heraia and other cities the Dionysos cult was embedded in the centre of civic life ${ }^{159}$. Especially at Athens the god was central both topographically and temporally in the religious order of the polis ${ }^{160}$. During the fifth century the theatre in Athens acquired even a function of presenting the Athenian polis to the rest of the Greek world ${ }^{161}$.

The fact that a number of elements in the Dionysos cults express a disruption of normality should not be taken at face value, as a revolt against the social order. According to Lewis possesion cults are frequently labelled as intrusions into the central religious system, while these cults in fact are essential to the existence of the social and

159 GRAF, op. cit. (n. 111), p. 74-96; M. MASSENZIO, La festa di Artemis Triklaria e Dionysos Aisymnetes a Patrai, in SMSR, 39 (1968), p. 101-132; DETIENNE, art. cit. (n. 123), p. 80; JOST, op. cit. (n. 111), p. 425 sq.; C. BÉRARD, C. B RON, Bacchos au cour de la cité. Le thiase dionysiaque dans l'espace politique, see Association (n. 16), p. 13-30; VERNANT, art. cit. (n. 16), p. 297 sq.

160 On the topographical position of the Athenian theatres see N.W. SLATER, The Lenean Theatre, in ZPE, 66 (1969), p. 255-264; H.-J. NEWIGER, Zwei Bemerkungen zur Spielstätte des attischen Dramas im 5. Jahrhundert v. Chr., in WS, N.F., 10 (1976), p. 80-92; F. KolB, Polis und Theater, in G. SEecK (hrsg.), Das griechische Drama, Darmstadt, 1979, p. 504-545; E. PöhlmanN, Die Proedrie des Dionysostheaters im 5. Jahrhundert und das Bühnenspiel der Klassik, in $M H, 38$ (1981), p. 129-146.

161 The ceremonies preceding the performances including the conspicious demonstration of Athenian power and wealth seem to have been a secular accretion to the ritual festival. I do not, therefore, agree with S.D. GoLDHILL, The Great Dionysia and Civic Ideology, in JHS, 107 (1987), p. 58-76 = in J.J. WINKLER, F.I. ZEITLIN (eds.), op. cit. (n. 3), p. 97-129, who maintains that these political ceremonies were the essence of the festival. He dismisses the ritual aspects of the Dionysia ("What happened on the days immediately before the days on which plays were performed...is also the part of the festival that interests me least for my present purposes" p. 59) thus distorting, in my opinion, the nature of the dramatic festival. Goldhill's idea of "the fundamentally questioning or agonistic nature of Greek tragedy" p. 59, seems to be more a statement of the author's preference than the result of a careful investigation. His notion that tragedy was questioning accepted norms of behaviour assumes a highly intellectual attitude in the audience to what is presented and in essence a moralistic drama. It views drama exclusively as a positive picture. I would propose a considerably more complex relationship between the dramatic action and the audience, see my work on tragic drama, DES BouvrIE 1990, op. cit. (n. *). 
religious order ${ }^{162}$. Likewise we should take account of the varied manifestations of Dionysos and accept their different relationships to the dominant order.

As a whole these manifestations with their varying emotional focus contributed to creating communities and their culture. The Dionysiac mystery cults seem to have promised their participants an exclusive membership after death. The consciousness of belonging to the elect in the nether world must have created a particular bond between the living. The secrecy of the cult established a boundary between members and not-members. It may be that the thrilling sense of exclusiveness in after-life constituted the fascination characteristic of this cult manifestation. The fact that mystery cults proliferated during the Hellenistic period may be related to the weakening of polis independance and accordingly an increasing need to establish communities within the vast territories of the post-Alexandrian world ${ }^{163}$. In the Classical age Dionysos seems to have included a greater part of the population.

Dionysos' force operated in the creative centre of society. This force manifested itself in the sense of communitas, the synchronisation of the moods of the group participating in the festival. Both the excitement that was roused and the liminal mood of liberation and inversion contributed to the creative process of renewal and revitalisation. Through diverse means of alcohol, rhythmic instruments and theatrical devices the god created a bond between those exposed to the experience. The effects ranged through different shades of euphoria from trance through festive hilarity at the symposion to fascination at the theatre spectacle. In this way the cult of Dionysos was essentially a collective process creating a network of relationships between the members of the congregation and connecting them with the god ${ }^{164}$.

162 LEWIS, op. cit. (n. 113).

163 W. Burkert, op. cit. (n. 17), p. 290-295, and ID., Ancient Mystery Cults, Cambridge, Mass, 1987 (Car Newell Jackson Lect.).

164 de Cazanove, art. cit. (n. 39); cf. M. Detienne, in M. Eliade (ed.), Encyclopedia of Religion, Vol. IV, New York-London, 1987, p. 358-361, s.u. 'Dionysos'. 
As a god of the polis Dionysos allows temporally chaos, the dissolution of society before order is reestablished ${ }^{165}$. The god not only represents the force of liminality, other deities do so as well. He seems particularly to represent the force that intoxicates his devotees in various degrees of euphoria creating communitas in the service of revitalising the cultural order.

University of Troms $\varnothing$

Synnøve DES BOUVRIE

School of languages and literature

N - 9037 Troms $\emptyset$

Norway

165 See especially GrAF, op. cit. (n. 111). 